Pak. j. sci. ind. res. Ser. A: phys. sci. 201356 (3) 151-164

\title{
Adsorptive Removal of Methylene Blue Dye by Melon Husk: Kinetic and Isothermal Studies
}

\author{
Abass Abiola Olajire ${ }^{a *}$, Abdur-rahim Adebisi Giwa ${ }^{a}$ and Isa Adewale Bello ${ }^{b}$ \\ ${ }^{a}$ Industrial and Environmental Chemistry Unit, Department of Pure and Applied Chemistry, \\ Ladoke Akintola University of Technology, Ogbomoso, Nigeria \\ bPhysical Chemistry Unit, Department of Pure and Applied Chemistry, \\ Ladoke Akintola University of Technology, Ogbomoso, Nigeria
}

(received February 10, 2012; revised May 4, 2012; accepted May 30, 2012)

\begin{abstract}
The adsorption capacity of methylene blue (MB) dye from aqueous solution onto raw melon husk (RMH) was investigated under various experimental conditions. Surface studies of RMH were investigated by fourier transform infrared (FTIR) and scanning electron microscopy (SEM). Batch studies were performed to evaluate the effect of various experimental parameters such as contact time, initial concentration of MB dye and dosage of RMH on the efficiency of the sorption process. Optimum conditions for $\mathrm{MB}$ dye removal were found to be at an adsorbent dosage of $8.0 \mathrm{~g} / \mathrm{L}$ of solution for an equilibrium time of 120 min. Lagergren, Elovich and Morris - Weber equations were employed to study kinetics of sorption process. The sorption process was very rapid at the initial stage as $80 \%$ of the dye was removed within the first 5 mins. The kinetics of the adsorption followed pseudo second order model with $\mathrm{R}^{2}$ values ranging from 0.999 to 1 for all initial dye concentrations studied. Equilibrium isotherms for the adsorption of MB dye on RMH were analysed by Freundlich, Langmuir and Temkin isotherm models and the goodness of fittings were inspected using linear regression analysis $\left(\mathrm{R}^{2}\right)$ and sum of square error (SSE). The equilibrium data were well described by Langmuir and Temkin equation at all range of operating parameters.
\end{abstract}

Keywords: melon husk, kinetics, isotherm, methylene blue dye, adsorption

\section{Introduction}

Basic dyes are the brightest class of water soluble dyes used by the textile industries and methylene blue is one of the most frequently used dyes in all industries (Reid, 1996). It dissociates into cation and chloride ion in aqueous solution (Tor and Cengeloglu, 2006). Presence of this dye in water leads to various health effects like eye burns and irritation to the gastrointestinal tract with symptoms of nausea, vomiting and diarrhoea. It may lead to methamoglobinemia, cyanosis and dyspnea, if inhaled directly. It may also cause irritations to the skin (Senthilkumaar et al., 2005; Ghosh and Bhattacharyya, 2002).

There are several methods which can be used to treat dye wastewater. These include biological, chemical and physical (Robinson et al., 2001). All these methods were found inefficient and incompetent because of the stability of the dye towards light, oxidizing agents and aerobic degradation. Among these methods, adsorption is widely used for its maturity and simplicity. Of different adsorbent materials, activated carbon is the most popular for the removal of pollutants from wastewater. However, its widespread use is restricted due to high cost (Babel *Author for correspondence; E-mail: olajireaa@yahoo.com and Kurniawan, 2003). As such, numerous alternative materials have been investigated to adsorb dyes from aqueous solution, using methylene blue as the model basic dye, such as guava leaf powder (Ponnusami et al., 2008), dehydrated wheat bran carbon (Özer and Dursun, 2007), diatomaceous silica (Al-Qodah et al., 2007), wheat shell (Bulut and Aydin, 2006), NaOHtreated pure kaolin (Ghosh and Bhattacharyya, 2002), bamboo charcoal (Zhu et al., 2009), silver fir (Abies amabilis) sawdust (Zafar et al., 2008) and activated carbon from sugar beet molasses (Aci et al., 2008).

Two important physicochemical aspects for the evaluation of adsorption processes as a unit operation are the adsorption equilibria and the adsorption kinetics. Equilibrium relationships between adsorbent and adsorbate are described by adsorption isotherms, usually the ratio between the quantity adsorbed and that remaining in the solution at a fixed temperature at equilibrium. In the study of adsorption isotherm, linear regression is frequently used to determine the best fitting isotherm. The linear least squares method with linearly transformed isotherms has also been widely applied to confirm experimental data, and isotherms using coefficients of determination. However, such transformations of 
nonlinear isotherms to linear forms implicitly alter their error structure and may also violate the error variance and normality assumptions of standard least squares (Ho, 2004; Ratkowsky, 1990). It has been reported that bias results from deriving isotherm parameters from linear forms of isotherms, for example, Freundlich parameters producing isotherms which tend to fit experimental data better at low concentrations and Langmuir isotherms tending to fit the data better at higher concentrations (Richter et al., 1989). Moreover, it has also been presented that using the linear regression method for comparing the best fitting isotherms is not appropriate (Ho, 2004). The advantage of using the nonlinear method is that there is no problem with transformations of non linear isotherms to linear forms and also they had the same error structures when the best fitting isotherms are compared (Ho, 2006).

In this study, melon husk, an agricultural waste material, was used as the adsorbent for its zero cost and convenient acquisition in local markets. A nonlinear method of three widely used isotherms, the Langmuir, Freundlich and Temkin, were compared in an experiment examining Methylene Blue adsorption onto melon husk. The data have also been explained on the basis of kinetic models.

\section{Materials and Methods}

Preparation of adsorbent. The melon husk used in this work was obtained from Aaradaa Market, a popular farm produce market in Ogbomoso, Southwestern Nigeria. Debris and other relatively big foreign materials were hand picked from the husk, after which it was thoroughly washed with distilled water, to remove soil and dust, drained and sun dried. The dried material was then ground, sieved into different particle sizes, and stored in air-tight containers as raw melon husk (RMH) adsorbent.

Adsorbent characterisation. The IR spectrum of the $\mathrm{RMH}$ was recorded in the range of $4000 \mathrm{~cm}^{-1}$ to $450 \mathrm{~cm}^{-1}$ using $\mathrm{KBr}$ disk as reference (Fig. 1). The scanning electron microscope (Hitachi 2300 Scanning electron microscope) was used to study the surface morphology of the adsorbent prepared from melon husk (Fig. 2). Samples were coated with gold before being subjected to SEM analysis. All physicochemical characteristics of the adsorbents were determined using standard methods (APHA, AWWA, WEF,1995; ISI, 1989; Vogel, 1969) and are presented in Table 1.

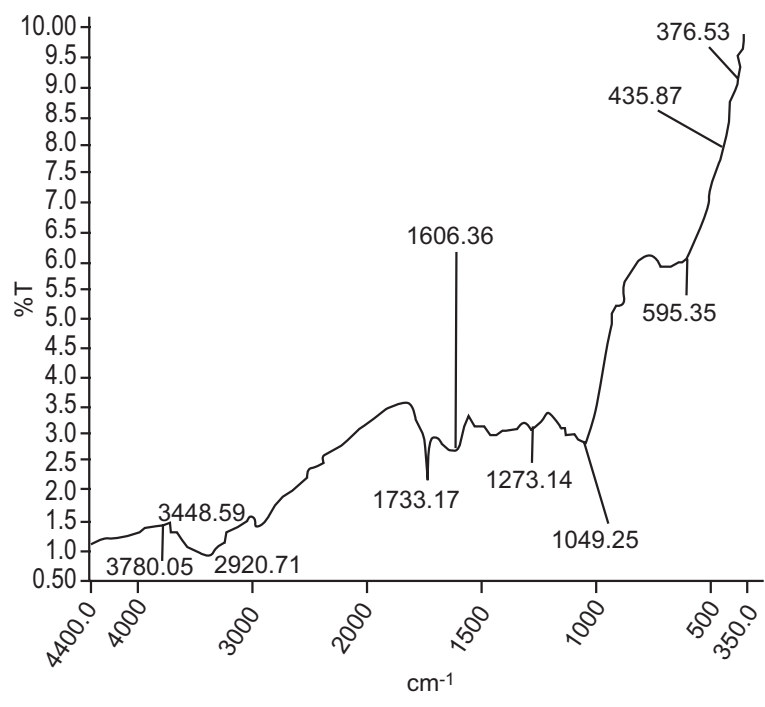

Fig. 1. FTIR spectrum of raw melon husk (RMH).

Table 1. Characteristics of the raw melon husk (RMH)

\begin{tabular}{ll}
\hline \hline Property & $\mathrm{RMH}$ \\
\hline Density $\left(\mathrm{g} / \mathrm{cm}^{3}\right)$ & 0.56 \\
Specific surface area $\left(\mathrm{m}^{2} / \mathrm{g}\right)$ & 284 \\
Moisture content $(\%)$ & 5.21 \\
Ash content $(\%)$ & $4-6$ \\
Solubility in water $(\%)$ & 0.75 \\
pH of 5\% slurry & 6.8 \\
\hline \hline
\end{tabular}

The effects of the $\mathrm{pH}$ on the equilibrium uptake of the $\mathrm{MB}$ by $\mathrm{RMH}$ were investigated over a range of $\mathrm{pH}$ values at the initial MB concentration of $50 \mathrm{mg} / \mathrm{L}$. Changes in the $\mathrm{pH}$ of the $\mathrm{MB}$ solution were adjusted with $0.1 \mathrm{M} \mathrm{HCl}$ or $1.0 \mathrm{M} \mathrm{NaOH}$ to attain a $\mathrm{pH}$ ranging from 4-9 for the MB. The suspensions were agitated for time intervals greater than the equilibrium time.

Adsorbate. Methylene blue (MB) (Colour index (C.I), 52015; $\lambda_{\max } 664 \mathrm{~nm}$; molecular weight, 355.90), a cationic dye, used in this study was obtained in commercial purity (M \& B Laboratory Chemicals), and was used without any further purification.

A stock solution of the dye was prepared by dissolving an accurately weighed quantity of the dye $(1.000 \mathrm{~g})$ in deionized distilled water $\left(\mathrm{ddH}_{2} \mathrm{O}\right)$ to make a $1000 \mathrm{mg} / \mathrm{L}$ solution. The experimental solutions of desired concentrations were prepared by accurately diluting the stock solution with $\mathrm{ddH}_{2} \mathrm{O}$. 


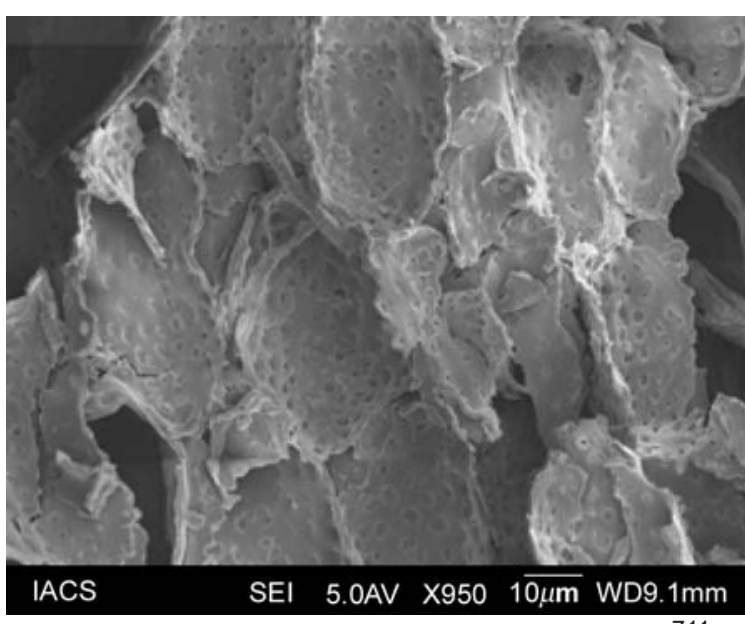

(a) $\mathrm{RMH}(\mathrm{X} 950)$

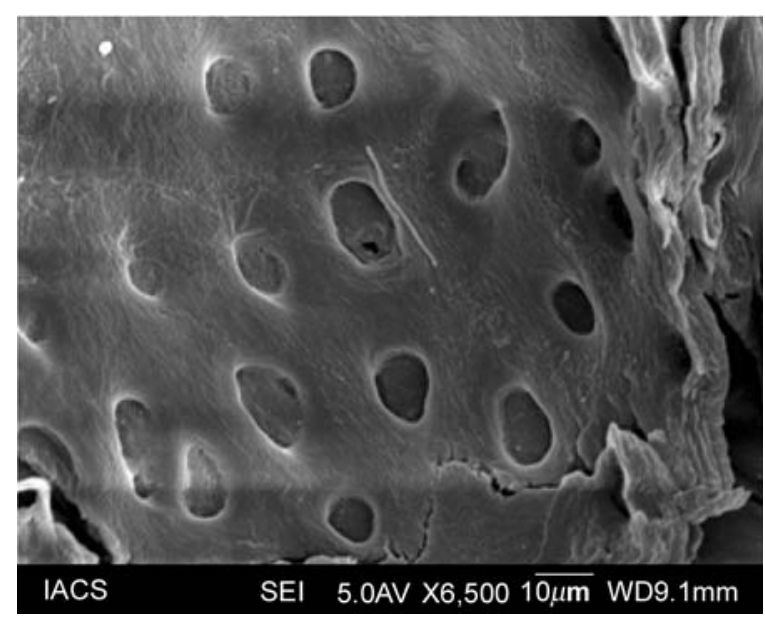

(b) RMH (X 6,500)

Fig. 2. SEM images of RMH at different magnifications (a) x 950, (b) x 6,500.

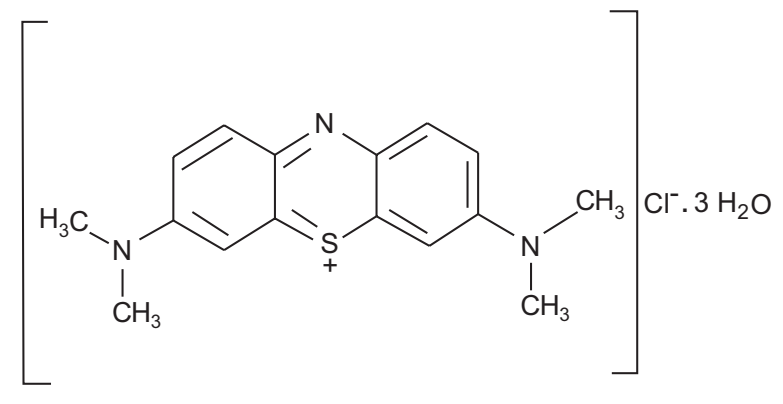

Methylene blue; C.I, 52015

Mol. weight, 355.90

Batch studies. For each study, a $25 \mathrm{~mL}$ of MB dye solution (of varying concentrations, ranging from 5 to $500 \mathrm{mg} / \mathrm{L}$ ) was prepared in a $250 \mathrm{~mL}$ leak-proof reaction bottles and a varying amount of adsorbent, ranging from 0.025 to $0.75 \mathrm{~g}$, was added to each bottle. The bottles were tightly fixed in a horizontal shaker (SM 101 by Surgafriend Medicals) and the shaking proceeded for $2 \mathrm{~h}$ to establish equilibrium, after which the mixture was left to settle for $10 \mathrm{~min}$ and then filtered.

The absorbance of the filtrate was determined with uv-visible Spectrophotometer (Genesys 10 uv-vis scanning spectrophotometer) adjusted at $\lambda_{\max }(664 \mathrm{~nm})$ of MB dye. By referring to the calibration curve of the dye, the corresponding concentration of the dye in the equilibrium solution was obtained. The percentage removal of MB dye and equilibrium adsorption uptake, $\mathrm{q}_{\mathrm{e}}(\mathrm{mg} / \mathrm{g})$ was calculated using the following relationships:

$$
\begin{aligned}
& \% \text { sorption }=\frac{100\left(C_{o}-C_{t}\right)}{C_{o}} . \\
& q_{e}=\frac{\left(C_{o}-C_{e}\right) V}{m}
\end{aligned}
$$

where:

$\mathrm{q}_{\mathrm{e}}$ is the amount of MB dye adsorbed $(\mathrm{mg} / \mathrm{g})$ at equilibrium; $\mathrm{C}_{\mathrm{o}}$ and $\mathrm{C}_{\mathrm{t}}$ are the initial concentration (at $t=0$ ) and its concentration at time $\mathrm{t}=\mathrm{t}(\mathrm{mg} / \mathrm{L}) ; \mathrm{m}$ is the mass of RMH (g); V is the volume of MB dye (L).

Error functions. The most common way to validate the isotherms is by inspecting the goodness of fit using linear regression coefficients $\mathrm{R}^{2}$. The $\mathrm{R}^{2}$ in the range of 0.9 to 1 indicates that the isotherms have a satisfying agreement to the particular adsorption system in which the value close to 1 is highly desirable. However, an occurrence of the inherent bias resulting from the linearization might affect the final judgment. Therefore, an additional nonlinear regression error function has been considered to further validate the applicability of the tested isotherms.

The sum of square error (SSE) provides a better fit at the higher concentration data as the magnitude of errors and the square of the errors increase with an increment in concentration (Gunay, 2007). The mathematical formula of SSE used in this study is given by the following equation (Arslanoglu et al., 2005; Tseng et al., 2003).

$$
\mathrm{SSE}=\sqrt{\Sigma\left(\mathrm{q}_{\mathrm{e}, \text { exp. }}-\mathrm{q}_{\mathrm{e}, \text { cal. }}\right)^{2} / \mathrm{N}}
$$


where:

$\mathrm{q}_{\mathrm{e}, \mathrm{cal}}$ is the amount of sorbate adsorbed at equilibrium calculated from the model (mg/g), $\mathrm{q}_{\mathrm{e}, \text { exp }}$ is the equilibrium value obtained from experiment $(\mathrm{mg} / \mathrm{g})$ and $\mathrm{N}$ is the number of data points.

\section{Results and Discussion}

The adsorbent prepared from raw melon husk (RMH) was studied for dye adsorption and the results, thus obtained, were analysed for the sorption efficiency of dye from aqueous solution, under different experimental conditions. The results of the studies are explained in the following sections.

Adsorbent characterisation. The FTIR spectrum of RMH (Fig. 1) displays a number of absorption peaks, indicating the complex nature of the material under study. The FTIR spectroscopic analysis indicated broad bands at $3448 \mathrm{~cm}^{-1}$ representing bonded-OH in the oxygen-containing functional groups. The positions of the C-H $\left(2920 \mathrm{~cm}^{-1}\right)$, aliphatic C-C $\left(1273 \mathrm{~cm}^{-1}\right)$ and aromatic $\mathrm{C}=\mathrm{C}\left(1604 \mathrm{~cm}^{-1}\right)$ and carboxyl/carbonyl $\left(1733 \mathrm{~cm}^{-1}\right)$ vibrations, contributed by those in structure of cellulose, hemicellulose and lignin, are indicated by the spectrum of RMH (Fig. 1) (Olajire, 2012; Langmuir, 1918). Thus, the FTIR analysis indicates that the RMH is represented by functional groups such as $\mathrm{COOH}$, $\mathrm{C}=\mathrm{O}$, and $\mathrm{C}=\mathrm{C}$ that could be potential adsorption sites for interaction with the methylene blue dye.

The scanning electron microscope (SEM) was used to study the surface morphology of the adsorbent (Fig. 2). The textural structure of raw melon husk (RMH) was presented as scanning electron micrographs of two different magnifications (x 950, x 6,500). Studies on the adsorbent's surface topography could provide important information on the degree of interaction between the adsorbent particles and the dye molecules (Mas Rosemal and Kathiresan, 2009). The SEM images of the adsorbent showed the irregular texture and porous nature of the surface of RMH (Fig. 2). The seemingly rough surface of the adsorbent is an indication of high surface area (Demirbas et al., 2004).

The physicochemical characteristics of RMH are listed in Table 1 . The density and specific surface area of $\mathrm{RMH}$ were measured to be $0.56 \mathrm{~g} / \mathrm{cm}^{3}$ and $284 \mathrm{~m}^{2} / \mathrm{g}$. Other parameters such as moisture content, ash content, solubility in water and solution $\mathrm{pH}$ were determined to be $5.21 \%, 4-6 \%, 0.75 \%$ and 6.8 , respectively. As seen in the SEM (Fig. 2), the high surface area and the rough surface are requisite for an effective adsorbent.

Effect of sorbent dosage. The effect of sorbent dosage on MB dyesorption by RMH was studied (Fig. 3) by varying adsorbent dosage from $0.025 \mathrm{~g}$ to $0.750 \mathrm{~g}$ in $25 \mathrm{~mL}$ of $50 \mathrm{mg} / \mathrm{L}$ solution of the MB dye while keeping other parameters (contact time, agitation speed, particle size, temperature) constant.

As evident from Fig. 3, the adsorption capacity $\left(\mathrm{q}_{\mathrm{e}}\right)$ decreases with increasing adsorbent dosage. However, percent sorption increases very rapidly from 90.19 to $99.66 \%$ as the dosage of RMH was increased from $0.025 \mathrm{~g}$ to $0.200 \mathrm{~g}$ and stays almost constant up to $0.750 \mathrm{~g}$ of sorbent dosage. An increase in the sorption with the sorbent dosage can be attributed to greater surface area and the availability of more adsorption sites (Esmaili et al., 2008; Azhar et al., 2005). At higher dosage, however, the incremental dye sorption becomes low, as the surface dye concentration and MB dye solution come to equilibrium with each other.

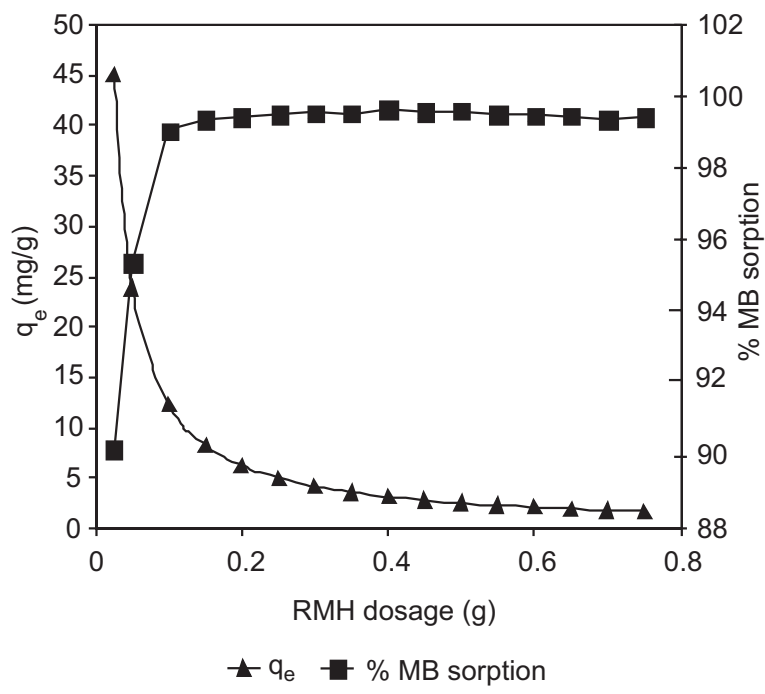

Fig. 3. Effect of adsorbent dosage on MB dye removal.

Effect of the initial concentration of MB dye. The effect of the initial concentration of MB dye on the adsorption by RMH is shown in Fig. 4. Adsorption capacity $\left(\mathrm{q}_{\mathrm{e}}\right)$ increases with increasing initial concentration of $\mathrm{MB}$ dye. The increase in the initial concentration of the dye enhances the interaction between the MB dye molecules and the surface of the adsorbent (Haris and Sathasvam, 2009). For instance, an increase 


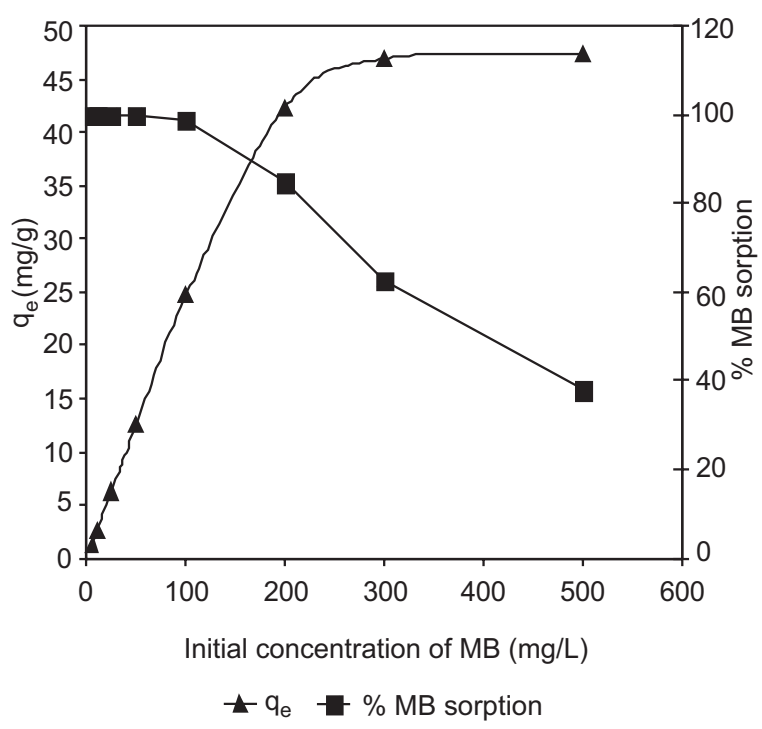

Fig. 4. Effect of MB dye concentration on sorption by RMH.

in the initial concentration of the MB dye from $5 \mathrm{mg} / \mathrm{L}$ to $500 \mathrm{mg} / \mathrm{L}$ led to an increase in adsorption capacity $\left(\mathrm{q}_{\mathrm{e}}\right)$ from 1.249 to $47.38 \mathrm{mg} / \mathrm{g}$. There was, however, a corresponding decrease in percent sorption from $99.89 \%$ to $37.91 \%$. Similar observation had also been reported by others (Azhar et al., 2005; Daniela and Doina, 2005), where decrease in percent sorption with increasing initial concentration of sorbate resulted in increased adsorption capacity.

The relatively higher percentage sorption observed at low initial concentrations of dye may be due to the high ratio of sorptive surface to the dye concentration, which implied that a fewer number of dye molecules were competing for the available binding sites on the adsorbent (Gupta and Mohapatra, 2003). With increasing MB dye initial concentration, the sorptive surface to dye concentration decreases leading to reduced percent sorption (Bansal et al., 2009).

Effect of contact time. Adsorption results revealed fast uptake of adsorbate species at the initial stages of contact period. In fact, in all the initial concentrations of MB dye used, over $80 \%$ sorption was achieved within the first $5 \mathrm{~min}$. As contact time increases, the adsorption of MB dye in the solution increases rapidly at the beginning with a gradual slow down until it remained at about $120 \mathrm{~min}$, which was then taken as the equilibrium time. A plot of percent sorption against time ( $t$ ) depicts a typical contact time for the sorption of MB dye by RMH (Fig. 5). The initial rapid phase, which

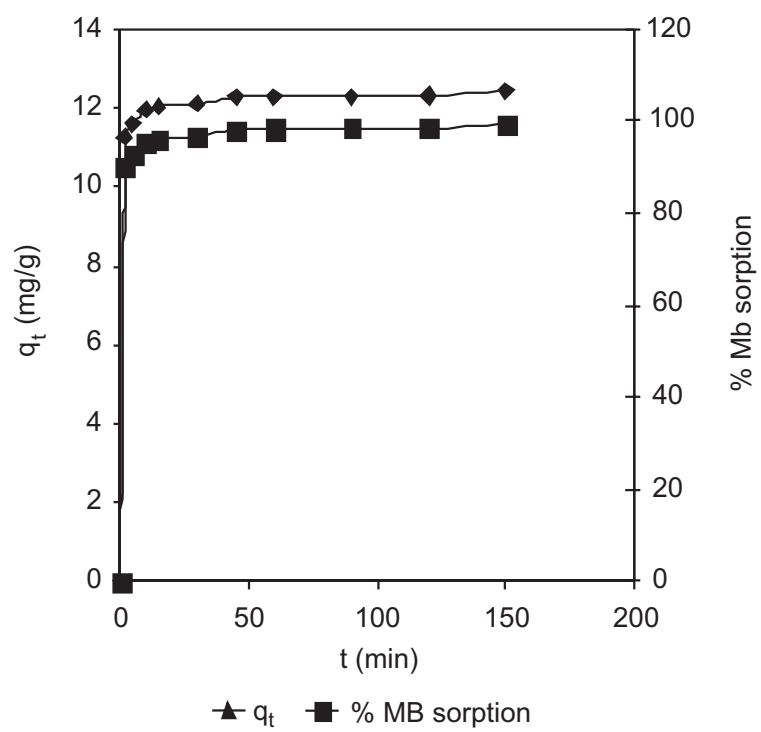

Fig. 5. Effect of contact time on sorption of MB onto RMH.

indicates a very spontaneous sorption process, may be due to the large number of vacant sites available at the initial period of the sorption (Wong et al., 2009). The increase in quantity adsorbed continued slowly until a quasistatic point is reached at about $120 \mathrm{~min}$.

Effect of $\mathbf{p H}$. The adsorption of MB by RMH were studied at various $\mathrm{pH}$ values of the MB solution (dosage $50 \mathrm{~mL}$, concentration $50 \mathrm{mg} / \mathrm{L}$ ), obtained by addition of varying proportions of $0.1 \mathrm{M} \mathrm{HCl}$ or $1.0 \mathrm{M} \mathrm{NaOH}$. The effect of $\mathrm{pH}$ on $\mathrm{MB}$ adsorption arose apparently from the charged properties of both MB and RMH. It is recognized that oxygen containing functional groups are present on the surface of RMH. These functional groups are subject to protonation/deprotonation, depending on $\mathrm{pH}$. An increase in $\mathrm{pH}$ usually results in surface functional groups partially (or fully) deprotonated and thus a loss of positive charge or buildup of negative charge. Figure 6 reveals that an increase in $\mathrm{pH}$ from 4 to 9 slightly increases the MB adsorption by RMH. The adsorptive increment resulted clearly from the deprotonation of the functional groups on the surface of RMH. The deprotonation resulted in an increased blockage of RMH surface by water molecules associated with negative charge. It is thus inferred that MB was primarily adsorbed on the negative surface of RMH.

Kinetic study. The modeling of the kinetics of adsorption of MB dye by RMH was investigated by four common models namely; the Largergren pseudo first order (Lagergren, 1898), Ho's pseudo second order 


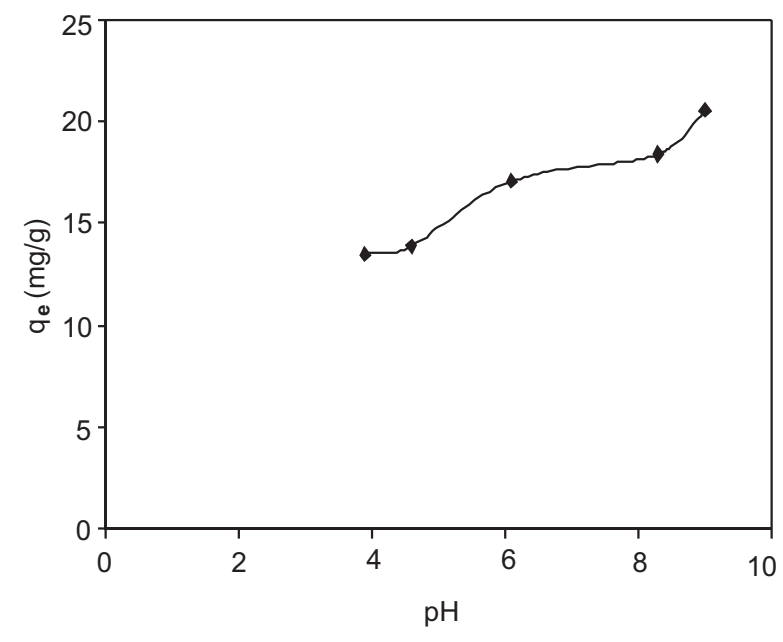

Fig. 6. Effect of solution $\mathrm{pH}$ on percentage removal of MB.

(Ho, 2006; 2004; Ho and Mckay, 1998), Elovich model (Zeldowitsch, 1934) and Morris-Weber (Weber and Morris, 1963) equations.

The pseudo first order model was described by Largergren as:

$$
\log \left(\mathrm{q}_{\mathrm{e}}-\mathrm{q}_{\mathrm{t}}\right)=\log \mathrm{q}_{\mathrm{e}}-\frac{\mathrm{k}_{1} \mathrm{t}}{2.303}
$$

The $\mathrm{q}_{\mathrm{e}}(\mathrm{mg} / \mathrm{g})$ is the amount of dye adsorbed at equilibrium, $\mathrm{q}_{\mathrm{t}}(\mathrm{mg} / \mathrm{g})$ is the amount of dye adsorbed at time $t$ and $k_{1}$ is the pseudo first order rate constant. A plot of $\log \left(\mathrm{q}_{\mathrm{e}}-\mathrm{q}_{\mathrm{f}}\right)$ versus agitation time gives a straight line (Fig. 7), with coefficient of correlation, $\mathrm{R}^{2}$, for the five different initial concentrations of MB dye investigated ranging from $0.8-0.9816$. The values of pseudo first order rate constant, $\mathrm{k}_{1}$, computed from the slope of the linear plot, ranged from $1.41 \times 10^{-2}-4.08 \times 10^{-2}$ $\min ^{-1}$ (Table 2). The experimental $\mathrm{q}_{\mathrm{e}}$ values did not agree with the calculated values based on the high values of its SSE. This shows that the adsorption of MB dye onto RMH does not follow a pseudo first order kinetics.

The pseudo second order model (Ho, 1995) is expressed as:

$$
\begin{aligned}
& \frac{\mathrm{t}}{\mathrm{q}_{\mathrm{t}}}=\frac{1}{\mathrm{~h}}+\frac{\mathrm{t}}{\mathrm{q}_{\mathrm{e}}} \\
& \mathrm{h}=\mathrm{k}_{2} \mathrm{q}_{\mathrm{e}}^{2}
\end{aligned}
$$

where:

$\mathrm{q}_{\mathrm{e}}$ is the amount of the solute adsorbed at equilibrium per unit mass of adsorbent $(\mathrm{mg} / \mathrm{g}), \mathrm{q}_{\mathrm{t}}$ is the amount of

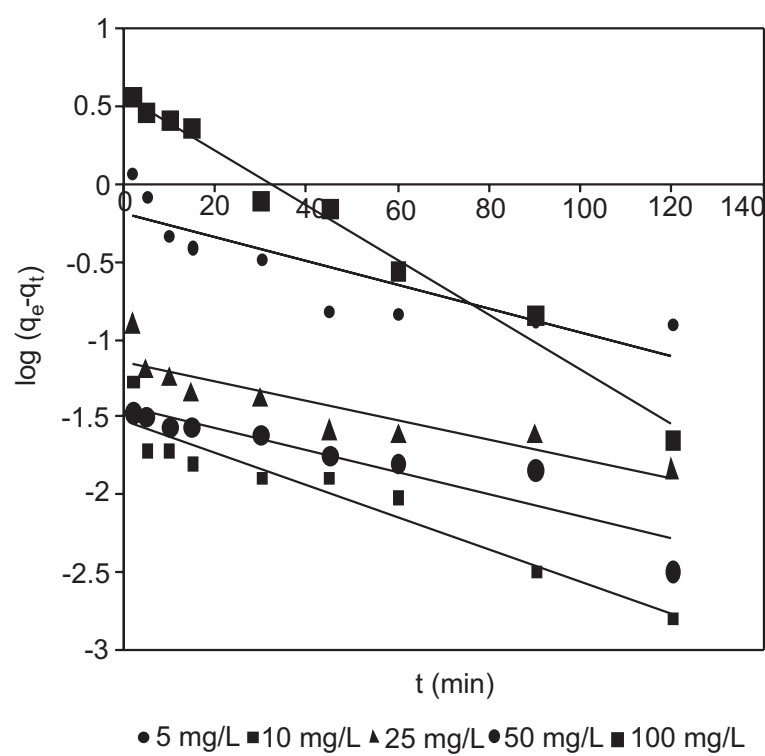

Fig. 7. Pseudo first order kinetic plot for the sorption of MB onto RMH.

solute adsorbed $(\mathrm{mg} / \mathrm{g})$ at any given time $\mathrm{t}(\mathrm{min})$ and $\mathrm{k}_{2}$ is the rate constant for pseudo second order adsorption $(\mathrm{g} / \mathrm{mg} / \mathrm{mm})$ and $\mathrm{h}$, known as the initial sorption rate.

If the sorption follows pseudo second order, $\mathrm{h}$, is described as the initial rate constant as $\mathrm{t}$ approaches zero. From the plot (Fig. 8), values of $k_{2}, R^{2}$ and $q_{e}$ were calculated (Table 2). The correlation coefficients obtained for the pseudo second order kinetic model are very high; and are close or equal to unity $(0.999-1)$ for the initial MB dye concentrations studied. There is also a very good agreement between the experimentally obtained and calculated values of $\mathrm{q}_{\mathrm{e}}$ based on the low values of its SSE (Table 2). This shows that the mechanism of the adsorption of MB dye by RMH can best be described by the pseudo second order kinetic model, based on the assumption that the rate limiting step may be chemisorption involving valence forces through sharing or exchange of electrons between the hydrophilic edge sites of the RMH and MB dye ions (Ho, 2006; Gucek et al., 2005). Increasing the initial concentration of MB dye from 5 to $100 \mathrm{mg} / \mathrm{L}$ causes an increase in sorption capacity from 1.23 to $24.51 \mathrm{mg} / \mathrm{g}$; which is also in agreement with observations of others (Malarvizhi and Sulochana, 2008; Oladoja et al., 2008).

The Elovich model is expressed as (Okiemen and Onyega, 1989; Sparks, 1986);

$$
\mathrm{q}_{\mathrm{t}} \frac{1}{\beta}=\operatorname{In}(\alpha \beta)+\frac{1}{\beta} \operatorname{Int}
$$


Table 2. Comparison of rate constants and other parameters for various kinetic models at different initial concentrations

\begin{tabular}{llllll}
\hline \hline Parameters & \multicolumn{5}{c}{$\mathrm{C}_{0}(\mathrm{mg} / \mathrm{L})$} \\
\cline { 2 - 5 } & 5 & 10 & 25 & 50 & 100 \\
\hline $\mathrm{q}_{\mathrm{e}}$ (expt.) & 1.232 & 2.468 & 6.192 & 12.426 & 24.347 \\
Pseudo first order & & & & \\
$\mathrm{R}^{2}$ & 0.864 & 0.910 & 0.800 & 0.741 & 0.982 \\
$\mathrm{k}_{1}$ & 0.016 & 0.024 & 0.014 & 0.017 & 0.041 \\
$\mathrm{q}_{\mathrm{e}}$ (cal.) & 0.037 & 0.031 & 0.070 & 0.632 & 3.725 \\
$\mathrm{SSE}(\%)$ & 103.2 & 129.7 & 125.5 & 508.9 & 427.3 \\
Pseudo second order & & & & \\
$\mathrm{R}^{2}$ & 1.000 & 1.000 & 1.000 & 1.000 & 0.999 \\
$\mathrm{k}_{2}$ & 2.106 & 3.358 & 1.306 & 0.165 & 0.037 \\
$\mathrm{q}_{\mathrm{e}}$ (cal.) & 1.231 & 2.468 & 6.188 & 12.407 & 24.509 \\
$\mathrm{~h}$ & 3.19 & 20.4 & 50.0 & 25.3 & 22.4 \\
$\mathrm{SSE}(\%)$ & 0.1 & 0.1 & 0.4 & 1.6 & 1.2 \\
Elovich model & & & & \\
$\mathrm{R}^{2}$ & 0.861 & 0.817 & 0.893 & 0.923 & 0.959 \\
$\alpha$ & $4.5 \times 10^{66}$ & $3.2 \times 10^{107}$ & $3.6 \times 10^{111}$ & $1.4 \times 10^{19}$ & $1.6 \times 10^{9}$ \\
$\beta$ & 133.33 & 104.17 & 42.92 & 4.05 & 1.07 \\
$\mathrm{SSSE}(\%)$ & 0.68 & 0.15 & 0.22 & 4.69 & 27.66 \\
Morris-weber & & & & & \\
$\mathrm{R}^{2}$ & & & & & \\
$\mathrm{~K}_{\text {id }}$ & 0.9689 & 0.6612 & 0.7394 & 0.7363 & 0.8619 \\
$\mathrm{X}_{\mathrm{i}}$ & 0.003 & 0.0033 & 0.0081 & 0.0844 & 0.3398 \\
$\mathrm{SSE}(\%)$ & 1.193 & 2.432 & 6.078 & 11.515 & 20.867 \\
\hline \hline
\end{tabular}

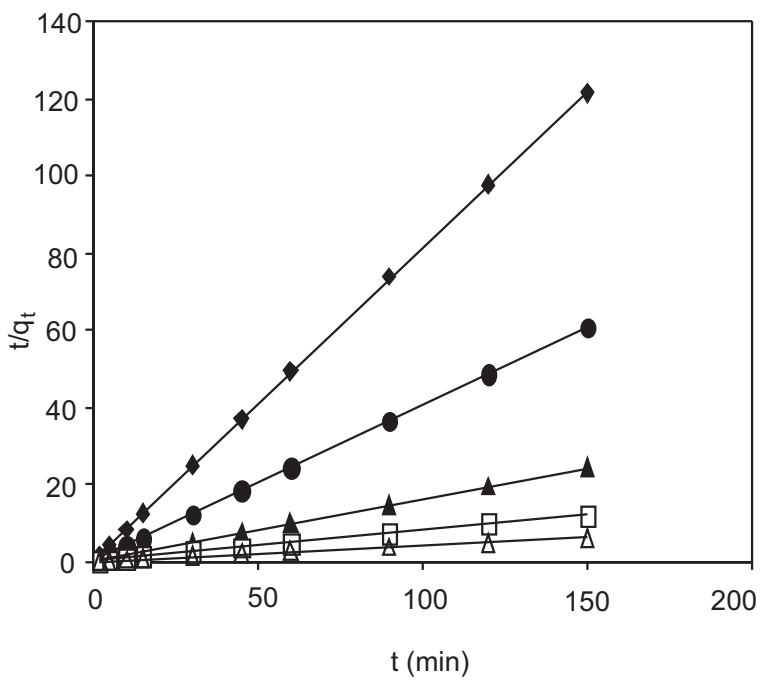

• $5 \mathrm{mg} / \mathrm{L} \bullet 10 \mathrm{mg} / \mathrm{L} \Delta 25 \mathrm{mg} / \mathrm{L} \square 50 \mathrm{mg} / \mathrm{L} \Delta 100 \mathrm{mg} / \mathrm{L}$

Fig. 8. Pseudo second order kinetic plot for the sorption of MB onto RMH. where $\alpha$ is the initial adsorption rate $(\mathrm{mg} / \mathrm{g} / \mathrm{min}), \beta$ is the desorption constant $(\mathrm{g} / \mathrm{mg})$ and $\mathrm{q}_{\mathrm{t}}$ is the amount of solute adsorbed $(\mathrm{mg} / \mathrm{g})$ at any given time, $\mathrm{t}(\mathrm{min})$.

A plot of $\mathrm{q}_{\mathrm{t}}$ versus Int gives a straight line with intercept and $\left(\frac{1}{\beta}\right)$ slope, (Fig. 9).

Table 2 shows the kinetic data of Elovich model for the adsorption of MB dye on RMH. The initial adsorption rate $\alpha$; desorption constant $\beta$; and the correlation coefficients, calculated from the plot for the different initial concentrations of MB dye are given in Table 2. The correlation coefficients obtained from the Elovich kinetic model are also high; ranging from 0.8714 to 0.9591 . Thus, Elovich equation could also be a good model for the adsorption process (Igwe and Abia, 2007).

The relationship between the initial concentrations of $\mathrm{MB}$ dye, $\mathrm{C}_{\mathrm{o}}$ and the Elovich initial adsorption rate $a$, was also investigated. As shown in the Table 2, the values of $\alpha$ increase with increasing $C_{0}$, until a maximum 


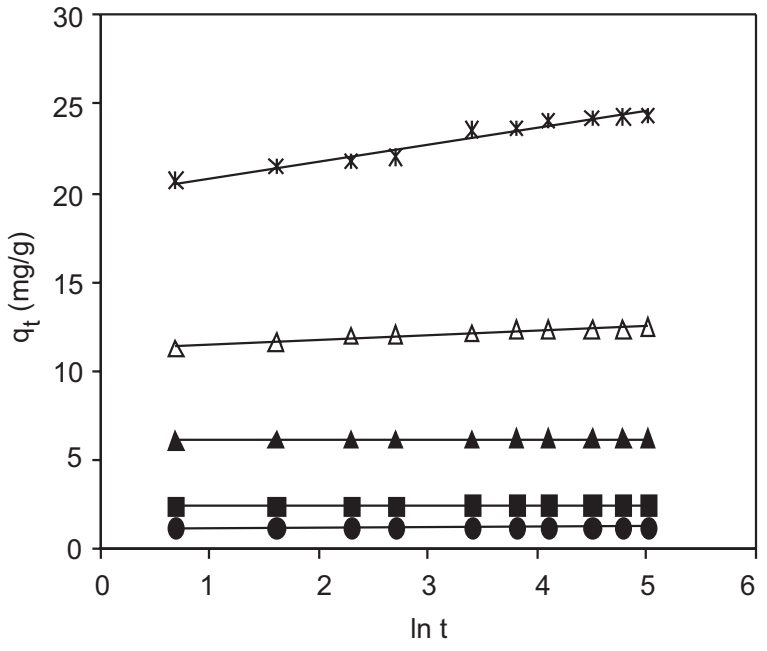

- $5 \mathrm{mg} / \mathrm{L} \square 10 \mathrm{mg} / \mathrm{L} \Delta 25 \mathrm{mg} / \mathrm{L} \Delta 50 \mathrm{mg} / \mathrm{L} * 100 \mathrm{mg} / \mathrm{L}$

Fig. 9. Elovich plot for the sorption of MB onto RMH.

is reached, after which a further increase in $\mathrm{C}_{0}$ resulted in a decrease in $\alpha$. For instance $\alpha$ rose from $4.5 \times 10^{66}$ to $3.6 \times 10^{111} \mathrm{mg} / \mathrm{g} / \mathrm{min}$ with an increase in $\mathrm{C}_{\mathrm{o}}$ from $5 \mathrm{mg} / \mathrm{L}$ to $25 \mathrm{mg} / \mathrm{L}$ (Table 2). Further increase in $\mathrm{C}_{\mathrm{O}}$ from $25 \mathrm{mg} / \mathrm{L}$ through $50 \mathrm{mg} / \mathrm{L}$ to $100 \mathrm{mg} / \mathrm{L}$ recorded a drastic fall in $\alpha$ from $3.6 \times 10^{111}$ to $1.6 \times 10^{9} \mathrm{mg} / \mathrm{g} / \mathrm{min}$. However, an inverse relationship was observed between $\mathrm{C}_{\mathrm{O}}$ and the Elovich model desorption constant $\beta$. For instance, an increase in $\mathrm{C}_{0}$ from $5 \mathrm{mg} / \mathrm{L}$ to $25 \mathrm{mg} / \mathrm{L}$ led to a decrease in $\beta$ from 133.333 to $42.918 \mathrm{~g} / \mathrm{mg}$ (Table 2).

The kinetics of sorption of MB dye was also investigated using Morris-Weber equation (Weber and Morris, 1963) in the following form:

$$
q_{t}=K_{i d} \sqrt{t}
$$

where:

$\mathrm{q}_{\mathrm{t}}$ is the sorbed concentration at time $t$, and $\mathrm{K}_{\mathrm{id}}$ is the rate constant of intraparticle transport. According to Morris and Weber (Weber and Morris, 1963), a plot of sorption capacity at a given time, $\mathrm{q}_{\mathrm{t}}$, versus $\mathrm{V}_{\mathrm{t}}$ should be a straight line if intraparticle diffusion is involved; and if it is the only rate determi-ning factor, the line passes through the origin. However, if the plot has an intercept (i.e., does not pass through the origin), it shows that intra particle diffusion may not be the only factor limiting the rate of the sorption process (Ho and Mckay, 2003). A modified form of Morris-Weber equation that takes care of boundary layer resistance was, therefore, proposed as (Igwe and Abia, 2007; Abia et al., 2006; Mckay and Poots, 1980):

$$
\mathrm{q}_{\mathrm{t}}=\mathrm{K}_{\mathrm{id}} \sqrt{\mathrm{t}}+\mathrm{X}_{\mathrm{i}}
$$

where:

$\mathrm{X}_{\mathrm{i}}$ depicts the boundary layer thickness (Abia et al., 2006).

The $\mathrm{q}_{\mathrm{t}}$ was plotted against, $\mathrm{t}^{1 / 2}$ for the sorption of MB on RMH for different initial dye concentrations (Fig. 10). The correlation coefficients obtained from the plots were not high $(0.6612-0.9689)$ and the straight lines do not pass through the origin (the intercepts $>0$ ). The deviation of these lines from the origin indicates that intra-particle diffusion may be a factor in the sorption process, but not the only controlling step (Onge et al., 2007). The values of $\mathrm{K}_{\mathrm{id}}$ computed from the slopes of the plot ranged from $0.003-0.3398 \mathrm{mg} / \mathrm{g} / \mathrm{min}$. The larger the intercept, the greater is the contribution of the surface sorption (boundary layer resistance) in the rate-limiting step (Arvoli and Thenkuzhali, 2008). Both $\mathrm{K}_{\mathrm{id}}$ and $\mathrm{X}_{\mathrm{i}}$ have direct relationship with the initial concentration of MB dye (Table 2). Evidently from our results, the higher the initial concentration, the greater is the effect of boundary layer and its contribution on the rate determining step.

Adsorption isotherm models. An adsorption isotherm is the relationship between the adsorbate in the liquid phase and the adsorbate adsorbed on the surface of the

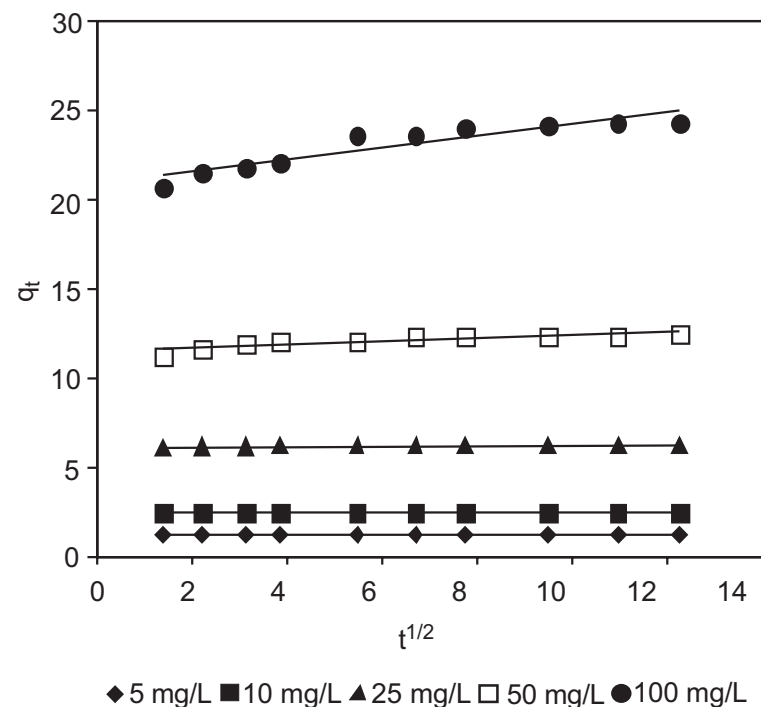

Fig. 10. Morris Weber equation for the sorption of MB onto RMH. 
adsorbent at equilibrium at constant temperature. The equilibrium adsorption isotherm is very important to design the adsorption systems. For solid liquid systems, several isotherms are available. The Langmuir isotherm takes an assumption that the adsorption occurs at specific homogeneous sites within the adsorbent and the equation takes the form (Ho et al., 2002; Langmuir, 1918):

$$
\mathrm{q}_{\mathrm{e}}=\frac{\mathrm{q}_{\mathrm{m}} \mathrm{k}_{\mathrm{a}} \mathrm{C}_{\mathrm{e}}}{1+\mathrm{k}_{\mathrm{a}} \mathrm{C}_{\mathrm{e}}}
$$

where:

$\mathrm{qe}$ is the amount of dye adsorbed per unit mass at equilibrium $(\mathrm{mg} / \mathrm{g}) ; \mathrm{q}_{\mathrm{m}}$ is the maximum possible amount of dye that can be adsorbed per unit mass of adsorbent $(\mathrm{mg} / \mathrm{g}) ; \mathrm{C}_{\mathrm{e}}$ is concentration of sorbate in the solution at equilibrium $(\mathrm{mg} / \mathrm{L}) ; \mathrm{k}_{\mathrm{a}}$ is the sorption equilibrium constant. The linearised form of equation (10) is:

$$
\frac{C_{e}}{q_{e}}=\frac{1}{k_{a} q_{m}}+\frac{C_{e}}{q_{m}}
$$

A plot of $\frac{C_{e}}{q_{e}}$ versus $C_{e}$ gives a straight line (Fig. 11), with a slope of $\frac{1}{\mathrm{q}_{\mathrm{m}}}$ and intercept $\frac{1}{\mathrm{k}_{\mathrm{a}} \mathrm{q}_{\mathrm{m}}}$. The effect of

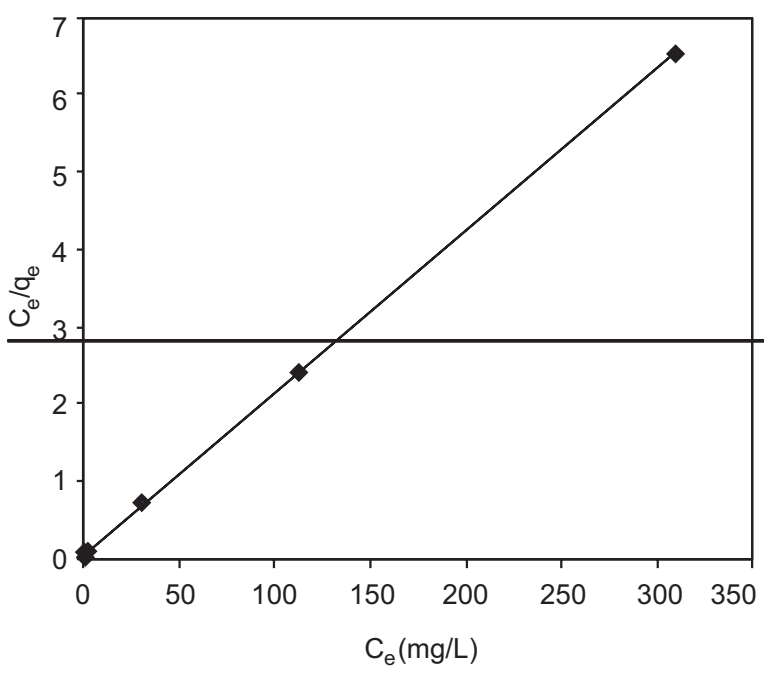

Fig. 11. Langmuir sorption isotherm of $\mathrm{MB}$ onto RMH. isotherm shape can also be used to predict, whether an adsorption system is "favourable" or "unfavourable." According to Hall et al. (1966), the essential features of the Langmuir isotherm can be expressed in terms of a dimensionless constant separation factor or equilibrium parameter $\mathrm{K}_{\mathrm{R}}$, which is defined by the following relationship:

$$
\mathrm{K}_{\mathrm{R}}=\frac{1}{1+\mathrm{k}_{\mathrm{a}} \mathrm{C}_{\mathrm{o}}}
$$

where:

$\mathrm{K}_{\mathrm{R}}$ is dimensionless separation factor; $\mathrm{K}_{\mathrm{a}}$ is Langmuir constant $(\mathrm{L} / \mathrm{mg}) ; \mathrm{C}_{\mathrm{o}}$ is the initial concentration of sorbate $(\mathrm{mg} / \mathrm{L})$. The separation factor, $\mathrm{K}_{\mathrm{R}}$ indicates the nature of the adsorption process as given in Table 3 . The Langmuir isotherm model was chosen for the estimation of maximum adsorption capacity corresponding to complete monolayer coverage on the RMH. The Langmuir data are given in Table 4. The sorption capacity, $\mathrm{q}_{\mathrm{m}}$, which is a measure of the maximum sorption capacity corresponding to complete monolayer coverage showed that RMH adsorbent seemed to have a high monolayer adsorption capacity. The adsorption coefficient, $\mathrm{K}_{\mathrm{a}}$, related to the apparent energy (surface energy) of sorption was found to be $0.991 \mathrm{~L} / \mathrm{mg}$. The high magnitude of $\mathrm{q}_{\mathrm{m}}(47.39 \mathrm{mg} / \mathrm{g})$ indicates that the amount of MB dye per unit weight of sorbent (to form a complete monolayer on the surface) seems to be high value of $\mathrm{q}_{\mathrm{m}}$ when compared with other adsorbents used on MB dye (Table 5) showed that raw melon husk could also be a good adsorbent material for MB. A moderate $\mathrm{K}_{\mathrm{a}}$ value implies moderate surface energy in MB dye$\mathrm{RMH}$ system, thus indicating a probable moderate binding between MB dye and sorbent (Aksu and Yener,

Table 3. The process of nature of separation factor

\begin{tabular}{ll}
\hline \hline $\mathrm{K}_{\mathrm{R}}$ & Type of adsorption process \\
\hline $\mathrm{K}_{\mathrm{R}}>1$ & Unfavourable \\
$\mathrm{K}_{\mathrm{R}}=1$ & Linear \\
$0<\mathrm{K}<1$ & Favourable \\
$\mathrm{K}_{\mathrm{R}}=0$ & Irreversible \\
\hline \hline
\end{tabular}

Table 4. Isotherm model parameters for adsorption of MB dye onto RMH

\begin{tabular}{lllllllll}
\hline \hline Models & $\mathrm{R}^{2}$ & $\mathrm{SSE}(\%)$ & $\mathrm{k}_{\mathrm{f}}$ & $1 / \mathrm{n}$ & $\mathrm{q}_{\max }$ & $\mathrm{k}_{\mathrm{a}}$ & $\mathrm{a}$ & $\mathrm{b}$ \\
\hline Freundlich & 0.873 & 11.28 & 12.578 & 0.3114 & - & - & - & - \\
Langmuir & 0.999 & 3.71 & - & - & 47.39 & 0.991 & - & - \\
Temkin & 0.983 & 2.46 & - & - & - & - & 23.17 & 4.72 \\
\hline \hline
\end{tabular}


Table 5. Comparison of maximum monolayer adsorption (adsorption capacities) of some adsorbents for methylene blue

\begin{tabular}{lll}
\hline \hline Adsorbent & $\mathrm{q}_{\mathrm{m}}\left(\mathrm{or} \mathrm{Q}_{\mathrm{o}}\right)(\mathrm{mg} / \mathrm{g})$ & References \\
\hline Miswak leaves & 200 & Elmorsi, (2011) \\
Natural Jordanian Tripoli & 16.62 & Alzaydien, (2009) \\
Posidonia oceanica fibre & 5.56 & Ncibi et al., (2007) \\
Palm kernel fibre & 671.78 & Ofomaja, (2007) \\
Neem leaf powder & 19.61 & Bhattacharya and Sharman, ((2005) \\
Raw walnut tree sawdust & 19.41 & Ansori and Mosayebzadeh, (2010) \\
Polypyrrole treated walnut sawdust & 34.36 & Ansori and Mosayebzadeh, (2010) \\
Cysteseira barbatula kutzing (a brown alga) & 21.93 & Caparkaya and Cavas, (2008) \\
Bamboo dust carbon & 143.20 & Kannan and Sundaram, (2001) \\
Raw melon husk & 47.39 & This study \\
\hline \hline
\end{tabular}

2001). The values of $K_{R}$ for initial dye concentrations from 5 to $500 \mathrm{mg} / \mathrm{dm}^{3}$ were found to range from 0.00209 to 0.01680 . The $\mathrm{K}_{\mathrm{R}}$ values indicate that adsorption is more favourable for the Methylene blue/RMH system as they fall between 0 and 1 (Table 3). The Langmuir model shows a strong conformation to experimental data based on satisfactorily values of the obtained linear regression coefficient, $\mathrm{R}^{2}$ and nonlinear error analysis (Table 4).

The Freundlich isotherm is an empirical equation employed to describe the heterogeneous system (Freundlich, 1906). The equation is given below:

$$
\mathrm{q}_{\mathrm{e}}=\mathrm{K}_{\mathrm{f}} \mathrm{C}_{\mathrm{e}}^{1 / \mathrm{n}}
$$

The linear form of the equation is:

$$
\log \mathrm{q}_{\mathrm{e}}=\log \mathrm{k}_{\mathrm{f}}+\frac{1}{\mathrm{n}} \log \mathrm{C}_{\mathrm{e}}
$$

where:

$\mathrm{q}_{\mathrm{e}}$ is the amount of MB dye adsorbed per unit mass of adsorbent $(\mathrm{mg} / \mathrm{g}) ; \mathrm{K}_{\mathrm{f}}(\mathrm{L} / \mathrm{g})$ and $\mathrm{n}$ are Freundlich constants which are measures of adsorption capacity and intensity of adsorption respectively (Malik, 2004), $\mathrm{C}_{\mathrm{e}}$ is the equilibrium concentration in $\mathrm{mg} / \mathrm{L}$.

From the straight line, obtained by plotting $\log \mathrm{q}_{\mathrm{e}}$ against $\log C_{e}$ (Fig. 12), the corresponding slope and intercept can be determined from $1 / \mathrm{n}$ and $\log \mathrm{K}_{\mathrm{f}}$ values. The Freundlich data are given in Table 4, with regression factor, $\mathrm{R}^{2}$, of 0.8732 and sum of error square (SSE) of 11.28. The values of Freundlich parameters $n$ and $K_{f}$ are 3.211 (i.e. $1 / \mathrm{n}=0.311$ ) and 12.578 , respectively. From the Freundlich equation, the high value of $\mathrm{K}_{\mathrm{f}}$ of RMH (12.578) indicates high uptake of MB dye from aqueous solution (Aksu and Yener, 2001). Furthermore, it was observed that the $n$-value satisfy the condition(s)

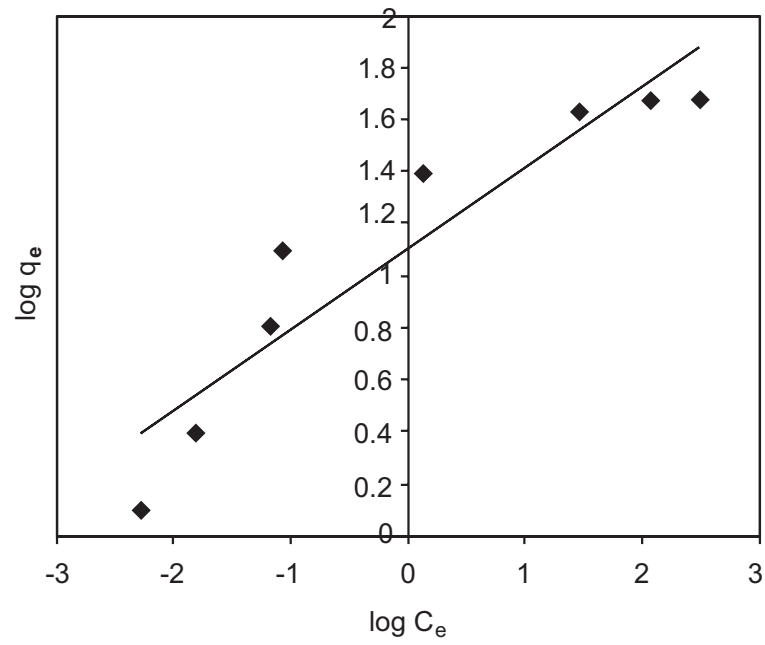

Fig. 12. Freundlich sorption isotherm of MB dye onto RMH.

of heterogeneity (Khalid et al., 2000), i.e $1<\mathrm{n}<10$ as well as $0<1 / \mathrm{n}<1$. The value of $1 / \mathrm{n}$ less than 1 describes a favourable nature of methylene blue adsorption onto $\mathrm{RMH}$, however, the model is not able to describe the experimental data properly because of the poor linear correlation and high SSE values (Table 4).

Temkin isotherm. Temkin isotherm model was used to test the adsorption potential of RMH to MB. This model is taking into account the effects of indirect adsorbate/adsorbate interactions on the adsorption process. Furthermore, the model is assuming that the heat of adsorption $\left(\Delta \mathrm{H}_{\mathrm{ads}}\right)$ of all molecules in the layer decreased linearly by increasing the coverage. The Temkin isotherm model is given by the following equation (Temkin and Pyzhev, 1940):

$$
\mathrm{q}_{\mathrm{e}}=\left(\left(\mathrm{RT} / \mathrm{b}_{\mathrm{T}}\right) \ln \left(\mathrm{K}_{\mathrm{T}} \cdot \mathrm{C}_{\mathrm{e}}\right)\right)
$$


The Temkin isotherm can be simplified to the following equation:

$$
\mathrm{q}_{\mathrm{e}}=\beta \ln \mathrm{K}_{\mathrm{T}}+\beta \ln \mathrm{C}_{\mathrm{e}}
$$

where:

$\beta=\left(\mathrm{R}_{\mathrm{T}}\right) / \mathrm{b}_{\mathrm{T}}$, is the Temkin constant, $\mathrm{T}$ is the absolute temperature in Kelvin and $\mathrm{R}$ is the universal gas constant $8.314 \mathrm{~J} / \mathrm{mol} / \mathrm{K}$. The constant $\mathrm{b}_{\mathrm{T}}$ is related to the heat of adsorption $(\mathrm{kJ} / \mathrm{mol}), \mathrm{K}_{\mathrm{T}}$ is the equilibrium binding constant $(\mathrm{L} / \mathrm{mol}$.) corresponding to the maximum binding energy.

The Temkin isotherm parameters generated from the Temkin isotherm plot (Fig. 13) are given in Table 4. Its correlation coefficient $\mathrm{R}^{2}$ of 0.983 is also high, which is an indication that the more energetic adsorption sites are occupied first by molecules of MB dye, and that the adsorption process is likely to be chemisorption (Lain-Chuen et al., 2007). The Temkin model shows a strong conformation to experimental data based on satisfactorily values of the obtained linear regression coefficient $\mathrm{R}^{2}$ and non linear error analysis (Table 4).

Error analysis. Ho (2004) reported that it is better to use the nonlinear analysis method for analysing the experimental data instead of linear regression analysis alone to compare the best fitting isotherms. When using the nonlinear method, there was no problem with transformations of nonlinear isotherms to linear forms. In this study, a nonlinear analysis was used to compare the best fitting isotherms using sum of square error.

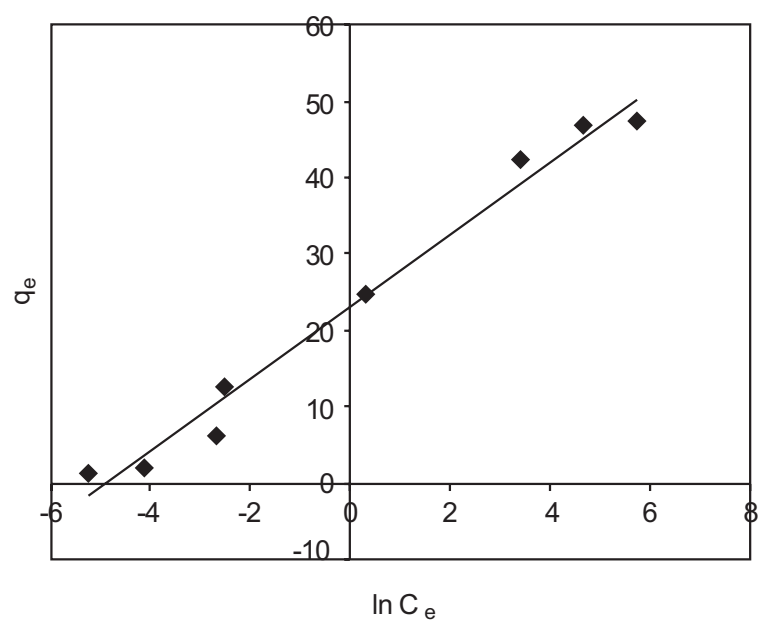

Fig. 13. Temkin sorption isotherm of MB dye onto RMH.
Analysis of non-linear error function (SSE test), revealed that both Langmuir and Temkin models are applicable since the resulting errors were very small (Table 4). These findings are very important to indicate that RMH might have homogenous and heterogeneous surface energy distributions. However, the Freundlich model is not able to describe the experimental data properly because of the poor linear correlation and high SSE values (Table 4). The SSE value more than $5 \%$ is not recommended due to intolerant margin of deviation between the experimental data and the model calculated data.

Further verification of the applicability of the kinetic models was also tested with the sum of error squares (SSE) and linear regression. The higher the value of $\mathrm{R}^{2}$ and the lower the value of SSE, the better is the goodness of fit and therefore the applicability of the kinetic model. Values of SSE calculated from pseudo second order equation were very low at all the concentration range considered, when compared with those of others (Table 2), which further confirms the validity of the applicability of the pseudo second order kinetic model to the present sorption process over the other kinetic models investigated in this study.

\section{Conclusion}

Raw melon husk (RMH) is able to adsorb methylene blue (MB) dye from aqueous solutions. Optimum sorption of MB dye by RMH is achieved at an adsorbent dosage of $0.200 \mathrm{~g} / \mathrm{L}$ of solution for an equilibrium time of $120 \mathrm{~min}$. The kinetic data can best be described by the pseudo second order kinetic model. It is successful to use the coefficient of determination of the non-linear method for comparing the best fit of the Langmuir, Freundlich and Temkin isotherms. The Temkin and the Langmuir isotherms had higher coefficients of determination than that of Freundlich isotherm but Langmuir might be the best fitting isotherm. Apparently, it can be concluded that the most applicable isotherm to describe MB dye RMH adsorption system are Langmuir and Temkin isotherms. Their values of regression coefficients $R^{2}$ and the nonlinear error function (SSE) are satisfactory. The Freundlih isotherm is the least applicable isotherm as the linear regression coefficients $\mathrm{R}^{2}$ were less than 0.9 and the sum of error square (SSE) is more than $5 \%$.

\section{References}

Abia, A.A., Didi, O.B., Asuquo, E.D. 2006. Modeling of $\mathrm{Cd}_{2}+$ sorption kinetics from aqueous solutions 
onto some thiolated agricultural waste adsorbents. Journal of Applied Sciences, 6: 2549-2556.

Aci, F., Nebioglu, M., Arslan, M., Imamoglu, M., Zengin, M., Kucukislamoglu, M. 2008. Preparation of activated carbon from sugar beet molasses and adsorption of methylene blue. Fresenius Environmental Bulletin, 17: 997-1001.

Aksu, Z., Yener, J. 2001. A comparative adsorption/ biosorption study of mono-chlorinated phenols onto various sorbents. Waste Management, 21: 695-702.

Al-Qodah, Z., Lafi, W.K., Al-Anber, Z., Al-Shannag, M., Harahsheh, A. 2007. Adsorption of methylene blue by acid and heat treated diatomaceous silica. Desalination, 217: 212- 224.

Alzaydieu, A.S. 2009. Adsorption of methylene blue from aqueous solution onto a low-cost natural Jordanian Tripoli. American Journal of Environmental Sciences, 5: 197-208.

Ansori, R., Musayebzadeh, Z. 2010. Removal of basic dye methylene blue from aqueous solutions using sawdust and sawdust coated with polypyrrole; Journal of Iranian Chemical Society, 7: 339-350.

APHA, AWWA, WEF. 1995. Standard Methods for the Examination of Water and Wastewater, American Public Health Association (APHA), American Water Works Association (AWWA) \& Water Environment Federation (WEF), $19^{\text {th }}$ edition, Washington, DC., USA.

Arslanoglu, F.N., Kar, F., Arslan, N. 2005. Adsorption of dark coloured compounds from peach pulp by using granular activated carbon. Journal of Food Engineering, 68: 409-417.

Arvoli, S., Thenkuzhali, M. 2008. Kinetics, mechanistics, thermodynamics and equilibrium studies on the adsorption of rhodamine $B$ by acid activated low cost carbon. E-Journal of Chemistry, 5: 187-200.

Azhar, S.S., Liew, G.A., Suhardy, D., Hafiz, F.K., Irfan, H.M.D. 2005. Dye removal from aqueous solution by using adsorption on treated sugarcane bagasse. American Journal of Applied Sciences, 2: 14991503.

Babel, S., Kurniawan, T.A. 2003. Low cost adsorbents for heavy metals uptake from contaminated water: A review. Journal of Hazardous Materials, 97: 219-243.

Bansal, M., Singh, D., Garg, V.K., Rose, P. 2009. Use of agricultural waste for the removal of nickel ions from aqueous solution: equilibrium and kinetic studies. International Journal of Environmental
Sciences and Engineering, 1: 108-114.

Bhattacharya, K.G., Sharma, A. 2005. Kinetics and thermodynamics of methylene blue adsorption on neem (Azadirachta indica) leaf powder. Dyes and Pigments, 65: 51-59.

Bulut, Y., Aydin, H. 2006. A kinetics and thermodynamics study of Methylene blue adsorption on wheat shells. Desalination, 194: 259-267.

Caparkaya, D., Cavas, L. 2008. Biosorption of methylene blue by a brown alga Cystaseira barbatula kutsing. Acta Chimica Slovania, 55: 547-553.

Daniela, S., Doina, B. 2005. Equilibrium and kinetic study of reactive dye brilliant red He-3b adsorption by activated charcoal. Acta Chimica Slovania, 52: 73-79.

Demirbas, E., Kobya, M., Senturk, E., Ozkan, T. 2004. Adsorption kinetics of chromium (VI) from aqueous solutions on the activated carbons prepared from agricultural wastes. Water $S A$, 30: 533-539.

Elmorsi, T.M. 2011. Equilibrium isotherms and kinetic studies of removal of methylene blue dye by adsorption onto Miswak leaves as a natural adsorbent. Journal of Environmental Protection, 2: 817-827.

Esmaili, A., Ghasemi, S., Rustaiyan, A. 2008. Evaluation of the activated carbon prepared of algae Gracilaria for the biosorption of $\mathrm{Cu}$ (II) from aqueous solution. American-Eurasian Journal Agricultural \& Environmental Sciences, 3: 810-813.

Freundlich, H.M.F. 1906. Über die adsorption in lösungen, Zeitschrift fur Physikalische Chemie, 57A: 385-470.

Ghosh, D., Bhattacharyya, K.G. 2002. Adsorption of Methylene blue on kaolinite. Applied Clay Science, 20: 295-300.

Gucek, A., Sener, S., Bilgen, S., Mazmanci, A. 2005. Adsorption and kinetic studies of cationic and anionic dyes on pyrophyllite from aqueous solutions. Journal of Colloid and Interface Sciences, 286: 53-60.

Gunay, A. 2007. Application of nonlinear regression analysis for ammonium exchange by natural (Bigadic) clinoptilolite. Journal of Hazardous Materials, 148: 708-713.

Gupta, R., Mohapatra, H. 2003. Microbial biomass: An economical alternative for removal of heavy metals from waste water. Indian Journal of Experimental Biology, 41: 945-966.

Hall, K.R., Eagleton, L.C., Acrivos, A., Vermeulen, T. 1966. Pore and solid diffusion kinetics in fixedbed adsorption under constant-pattern conditions. 
Industrial and Engineering Chemistry Fundamentals, 5: 212-223.

Haris, M.R.H., Sathasvam, K. 2009. The removal of methyl red from aqueous solution using banana pseudostem fibers. American Journal of Applied Sciences, 6: 1690-1700.

Ho, Y.S. 1995. Adsorption of Heavy Metals from Waste Streams by Peat. Ph.D. Thesis, The University of Birmingham, Birmingham, UK.

Ho, Y.S. 2004. Selection of optimum sorption isotherm. Carbon, 42: 2115-2116.

Ho, Y.S. 2004. Citation review of Lagergren kinetic rate equation on adsorption reactions. Scientometrics, 59: 171-177.

Ho, Y.S. 2006. Review of second order models for adsorption systems. Journal of Hazardous Materials, 136: 681-689.

Ho, Y.S. 2006. Isotherms for the sorption of lead onto peat: Comparison of linear and non-linear methods. Poland Journal Environmental Studies, 15: 81-86.

Ho, Y.S., Mc Kay, G. 1998. Sorption of dye from aqueous solution by peat. Chemical Engineering Journal, 70: 115-124.

Ho, Y.S., Mckay, G. 2003. Sorption of dyes and copper ions onto biosorbents. Process Biochemistry, 38: 1047-1061.

Ho, Y.S., Huang, C.T., Huang, H.W. 2002. Equilibrium sorption isotherm for metal ions on tree fern. Process Biochemistry, 37: 1421-1430.

Igwe, J.C., Abia, A.A. 2007. Adsorption kinetics and intraparticulate diffusivities for bioremediation of $\mathrm{Co}(\mathrm{II}), \mathrm{Fe}(\mathrm{II})$ and $\mathrm{Cu}(\mathrm{II})$ ions from wastewater using modified and unmodified maize cob. International Journal of Physical Sciences, 2: 119-127.

ISI, 1989. Activated Carbon, Powdered and GranularMethod of Sampling and Tests, IS 877, Bureau of Indian Standards, New Dehli, India.

Kannan, N., Sundaram, M.M. 2001. Kinetics and mechanism of removal of methylene blue by adsorption on various carbons - a comparative study. Dyes and Pigments, 51: 25-40.

Khalid, N., Ahmad, S., Toheed, A. 2000. Potential of rice husk for antimony removal. Applied Radiation Isotope, 52: 30-38.

Lagergren, S. 1898. Zur theorie der sogenannten adsorption gelöster stoffe. Kungliga Svenska Vetenskapsakademiens. Handlingar, Band 24: 1-39.

Langmuir, I. 1918. The adsorption of gases on plane surfaces of glass, mica and platinum. Journal of American Chemical Society, 40: 1361-1403.
Lain-Chuen, J., Cheng-Cai, W., Chung-Kung, L., Ting$\mathrm{Chu}$, H. 2007. Dyes Adsorption onto organoclay and MCM-41. Jounal of Environmental Engineering and Management, 17: 29-38.

Malik, P.K. 2004. Dye removal from wastewater using activated carbon developed from sawdust: Adsorption equilibrium and kinetics. Journal of Hazardous Materials, 113: 81-88.

Malarvizhi, R., Sulochana, N. 2008. Sorption isotherm and prepared from wood apple shell. Journal of Environmental Protection Sciences, 2: 40-46.

Mas Rosemal, H.M.H., Kathiresan, S. 2009. The removal of methyl red from aqueous solution using banana Psuedostem fibers. American Journal of Applied Sciences, 6: 1690-1700.

Mckay, G., Poots, J.P. 1980. Kinetics and diffusion processes in colour removal from effluent using wood as adsorbent. Journal of Chemical Technology Biotechnology, 30: 279-292.

Ncibi, M.C., Mahjoub, B., Seffen, M. 2007. Adsorptive removal of textile reactive dye using Posidonia oceanica (L.) fibrous biomass. International Journal of Environmental Science \& Technology, 4: 433-440.

Ofomaja, A.E. 2007. Kinetics and mechanism of methylene blue sorption onto palm kernel fibre. Process Biochemistry, 42: 16-24.

Okiemen, F.E., Onyega, V.U. 1989. Binding of cadmium, copper, lead and nickel ions with melon (Citrullus vulgaris) seed husk. Biological Waste, 29: 11-16.

Oladoja, N.A., Asia, I.O., Aboluwoye, C.O., Oladimeji, B., Ashogbon, A.O. 2008. Studies on the sorption of basic dye by rubber (Herea brasiliensis) seed shell. Turkish Journal of Engineering and Environmental Sciences, 32: 143-152.

Olajire, A.A. 2012. Principles and Applications of Spectroscopic Techniques, 268 pp., Sina2tees Publications, Nigeria.

Onge, S.A., Seng, C.E., Lom, V. 2007. Kinetic of adsorption of $\mathrm{Cu}(\mathrm{II})$ and $\mathrm{Cd}(\mathrm{II})$ from aqueous solution on rice husk and modified rice husk. Electronic Journal of Environmental, Agricultural and Food Chemistry, 6: 1764-1774.

Özer, A., Dursun, G. 2007. Removal of methylene blue from aqueous solution by dehydrated wheat bran carbon. Journal of Hazardous Materials, 146: 262-269.

Ponnusami, V., Vikram, S., Srivastava, S.N. 2008. Guava (Psidium guaiava) leaf powder: Novel adsorbent for removal of Methylene blue from aqueous 
solutions. Journal of Hazardous Materials, 152: 276-286.

Ratkowsky, D.A. 1990. Handbook of Nonlinear Regression Models. Marcel Dekker, New York, USA.

Reid, R. 1996. Go green-A sound business decision-1. Journal of the Society of Dyers and Colourists, 112: 103-105.

Richter, E., Schutz, W., Myers, A.L. 1989. Effect of adsorption equation on prediction of multicomponent adsorption equilibria by the ideal adsorbed solution theorys. Chemical Engineering Sciences, 44: 1609-1616.

Robinson, T., Mc Mullan, G., Marchant, R., Nigam, P. 2001. Remediation of dyes in textile effluent, a critical review on current treatment technologies with a proposed alternative. Bioresource Technology, 77: 247-255.

Senthilkumaar, S., Varadarajan, P.R., Porkodi, K., Subbhuraam, C.V. 2005. Adsorption of Methylene blue onto jute fiber carbon: Kinetics and equilibrium studies. Journal of Colloid Interface Sciences, 284: 78-82.

Sparks, D.L. 1986. Kinetics of Reactions in Pure and Mixed Systems in Soil Physical Chemistry, pp. 2125, CRC Press, Florida, USA.

Temkin, M.I., Pyzhev, V. 1940. Kinetics of Ammonia synthesis on promoted iron catalysts. Acta Physiochim, URSS, 12: 327-356.

Tor, A., Cengeloglu, Y. 2006. Removal of Congo red from aqueous solution by adsorption onto acid activated red mud. Journal of Hazardous Materials, 138: 409-415.

Tseng, R.L., Wu, F.C., Juang, R.S. 2003. Liquid phase adsorption of dyes and phenols using pinewood-based activated carbons. Carbon, 41: 487-495.

Vogel, A.I. 1969. A Text Book of Quantitative Inorganic Analysis, $3^{\text {rd }}$ edition, ELBS, London, UK.

Weber, Jr., W.J., Morris, J.C. 1963. Kinetics of adsorption on carbon from solution. Journal of the Sanitary Engineering Division-ASCE, 89: 31-59.

Wong, S.Y., Tan, Y.P., Abdullah, A.H., Ong, S.T. 2009. The removal of basic and reactive dyes using quartenised sugar cane bagasse. Journal of Physical Sciences, 20: 59-74.

Zafar, S.I., Bisma, M., Saeed, A., Iqbal, M. 2008. FTIR spectrophotometry, kinetics and adsorption isotherms modelling, and SEM-EDX analysis for describing mechanism of biosorption of the cationic basic dye Methylene blue by a new biosorbent (Sawdust of Silver Fir; Abies Pindrow). Fresenius Environmental Bulletin, 17: 2109-2121.

Zeldowitsch, J. 1934. Über den mechanismus der katalytischen oxydation von $\mathrm{CO}$ an $\mathrm{MnO} 2$. Acta Physicochimica URSS, 1: 449-464.

Zhu, Y.N., Wang, D.Q., Zhang, X.H., Qin, H.D. 2009. Adsorption removal of Methylene blue from aqueous solution by using bamboo charcoal. Fresenius Environmental Bulletin, 18: 369-376. 